\title{
Development of a high-performance liquid chromatography method for simultaneously analyzing Guanosine 5'-monophosphate (GMP) and Inosine 5'-monophosphate (IIMP) in food
}

\author{
Le Dinh Hai ${ }^{1}$, Nguyen Thi Thu ${ }^{2}$, Vu Thi Trang ${ }^{1 *}$, Le Thi Thuy ${ }^{1}$ \\ ${ }^{1}$ National Institute for Food Control, Hanoi, Vietnam \\ ${ }^{2}$ Hanoi University of Science and Technology, Hanoi, Vietnam
}

(Received: 22/10/2021; Accepted: 24/12/2021)

\section{Abstract}

This study aimed to develop a HPLC method to simultaneously analyze guanosine 5'-monophosphat (GMP) and inosine 5'-monophosphat (IMP) in food products. Sample preparation procedure was simple, fast. A C18 column $(250 \mathrm{~mm} \times 4.6 \mathrm{~mm}, 5 \mu \mathrm{m})$ was used as stationary phase, and a mixture of $10 \mathrm{mM}$ potassium dihydrogen phosphate and $5 \mathrm{mM}$ sodium heptanesulfonate was applied as mobile phase, and PDA detector at $250 \mathrm{~nm}$. The method validation followed AOAC criteria. Selectivity, linearity $\left(\mathrm{R}^{2}>0.999\right)$, recovery (IMP: 90.5 - 102.8 \%, GMP: 91.5 - 103.9 \%), repeatability (RSDR of IMP: $3.07 \%$ and GMP: $2.83 \%$ ) were acceptable to determination GMP and IMP in food matrix under AOAC guidelines. LOD of GMP and IMP were of 2.32 and $2.77 \mathrm{mg} / \mathrm{kg}$, respectively. This method was used to determination GMP, IMP in food products collected in Hanoi markets.

Keywords: GMP, IMP, HPLC, food matrix.

\section{INTRODUCTION}

Flavor enhancers are food additives used for enhancing the flavor of food products. Flavor enhancers have the main effect of increasing the taste of food and stimulating savory taste. GMP and IMP are flavor enhancers discovered by Japanese professors from the early XX century. They are usually added in soup, sauces, species, vegan products, etc with or without monosodium glutamate to form the like-meat taste (Umami taste) [1]. Brief information of IMP and GMP was showed in Table 1. Generally, GMP and IMP are considered as safety substances for human, so they are widely used in various countries as well as Vietnam [2]. Despite general safety, authorities still released recommendations of not using IMP and GMP for those who have nucleotide metabolic distortion or under one year old. Accordingly, a method to analyze IMP and GMP in food products would be developed.

Table 1. Brief information of IMP and GMP [2]

\begin{tabular}{|c|c|c|}
\hline & IMP & GMP \\
\hline IUPAC Name & Inosine-5'-monophotphat (IMP) & $\begin{array}{c}\text { Guanosine-5'-monophotphate } \\
\text { (GMP) }\end{array}$ \\
\hline INS code & 631 & 627 \\
\hline Molecular formula & $\mathrm{C}_{10} \mathrm{H}_{11} \mathrm{~N}_{4} \mathrm{Na}_{2} \mathrm{O}_{8} \mathrm{P}$ & $\mathrm{C}_{10} \mathrm{H}_{12} \mathrm{~N}_{5} \mathrm{Na}_{2} \mathrm{O}_{8} \mathrm{P}$ \\
\hline Structure formula & $\mathrm{Na}^{+-} \mathrm{O} \sum_{\mathrm{OH} \mathrm{O}}^{\mathrm{O}}$ & $\mathrm{Na}^{+\cdot} \mathrm{O} \sum_{\mathrm{OH} \mathrm{OH}}^{\mathrm{O}}$ \\
\hline $\begin{array}{l}\text { Maximum } \\
\text { absorbance } \\
\text { wavelength } \lambda \max (\mathrm{nm})\end{array}$ & 249 & 255 \\
\hline
\end{tabular}


Previous studies using thin layer chromatography [3], high-performance liquid chromatography (HPLC) with a photodiode array detector (PDA) [4-5], high-performance liquid chromatography (HPLC) with a mass spectrophotometry [6-7] were conducted to determine IMP and GMP content in sauce, potato, tomato, and milk, etc. However, the methods used PDA detector were selective, rapid, and more economical than others. Therefore, this study aimed to develop a method using HPLC-PDA to analyze GMP and IMP in food matrix samples.

\section{MATERIALS AND METHODS}

\subsection{Equipment}

HPLC system (Alliance - Waters) was equipped with high-pressure pump, automatic injector, PDA detector and Sunfire C18 column $(250 \mathrm{~mm} \times 4.6 \mathrm{~mm}, 5 \mu \mathrm{m})$; pH meter 744 (Mettler Toledo); Hermle Z383K centrifuge; analytical weigh (Mettler Toledo), etc.

\subsection{Chemicals and materials}

Standards: disodium 5'-inosinate, disodium 5'-guanylate (>99.0 \%) from Sigma Aldrich. Analytical chemicals: Potassium dihydrogen phosphate, ortho phosphoric acid, sodium heptane sulfonate, diethyl ether, etc from Merck.

The stock standard solutions were prepared by dissolving $100 \mathrm{mg}$ each of disodium 5 '-guanylate and disodium 5 '-inosinate in water in a $100 \mathrm{~mL}$ flask. Working standards at concentration of $0.5,1,5,10$, 20, 50, $100 \mathrm{ppm}$ were prepared by diluting the stock standard solutions with water into $10 \mathrm{~mL}$ volumetric flasks.

Samples including sausages, instant noodles, spices, sauses, etc were collected from local markets in

\subsection{Methods}

\subsubsection{Sample preparation}

Weigh, to the nearest $0,1 \mathrm{~g}$, about $3 \mathrm{~g}$ of homogenized samples in a $50 \mathrm{~mL}$ falcol tube. Samples were removed fatty portions by shaking horizontally with $20 \mathrm{~mL}$ organic solvent by shaker. Solvent was removed by centrifuging 6,000 rpm in five minutes, then pipetting out of the samples. Then, IMP and GMP were extracted with water by shaking. Organic solvents, time of extractions and the number of extractions with water were investigated. Aliquot of the extract, after centrifuged 6,000 rpm in five minutes, were transferred into $50 \mathrm{~mL}$ volumetric flask, then water was added to the mark. The extract was filtered through $0.45 \mu \mathrm{m}$ filters before being injected into HPLC.

\subsubsection{Analysis by HPLC}

The phosphate buffer was used as mobile phase because of polar analytes. Mobile phase composition, mobile phase concentration, and $\mathrm{pH}$ of mobile phase were assessed to study analitical conditions. Flow rate was set up at $0.8 \mathrm{~mL} / \mathrm{min}$ and GMP and IMP were mornitored at $250 \mathrm{~nm}$. Optimization was confirmed using retention times, peak sharpness, and resolution between two substances.

The analytical method was validated by creating a calibration curve from an array of working standards from 0.5 to $100 \mathrm{ppm}$. LOD and LOQ was defined as three and ten times of standard deviation (SD) value of results from ten times analyzing samples at concentration of five to seven times estimated LOD [8]. Trueness was examined through spike standard to samples at three levels of concentration. Repeatability was performed by repeating six times of procedure, reproducibility was performed by repeating four times of procedure for each sample by another analyzer in another day.

\section{RESULTS AND DISCUSSION}

\subsection{Mobile phase}

Solutions of 100 ppm IMP and 100 ppm GMP were injected to HPLC systems to identify each substance. Maximum absorbance wavelength $\left(\lambda_{\max }\right)$ of IMP and GMP in water matched to previous data (Table 1). Accordingly, $\lambda_{\max }$ values were used to identify substances when developing analysis method.

The results of mobile phase composition optimization was showed in Figures 1, 2, 3 in which peak of IMP was the first one in the chromatographies. Regarding to the mobile phase using only potassium 
dihydrogen phosphate, IMP and GMP were not completely separated while two others could be seen as separated well. Furthermore, peaks were tailing and broadening when using ammonium acetate as mobile phase, while this was not observed with mixture of potassium dihydrogen phosphate and sodium heptanesulfonate.

Concentration of salts in mobile phase from 5 to $50 \mathrm{mM}$ was surveyed for optimization. From Figure 2, resolution between IMP and GMP and peak shape was improved when salt concentration rose. Concentration of $10 \mathrm{mM}$ potassium dihydrogen phosphate and $5 \mathrm{mM}$ sodium heptanesulfonate was chosen in this study because of well separation and limiting the effect of high salt concentration on HPLC system. $\mathrm{pH}$ of mobile phase has no effect on retention time of GMP and IMP, but it has relevance to peak shape (Figure 3). Peaks of IMP and GMP mobile phases with low $\mathrm{pH}$ became more symmetric than others with higher $\mathrm{pH}$.Therefore, $\mathrm{pH}$ of mobile phase was adjusted to $\mathrm{pH} 3$ for analyzing.

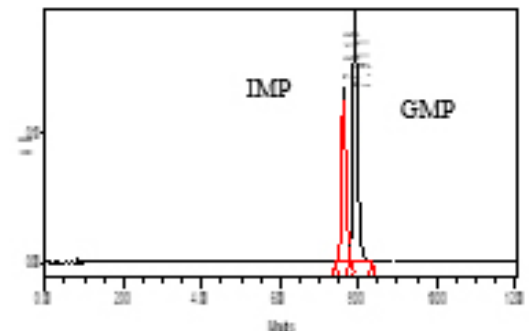

$\mathrm{KH}_{2} \mathrm{PO}_{4}$

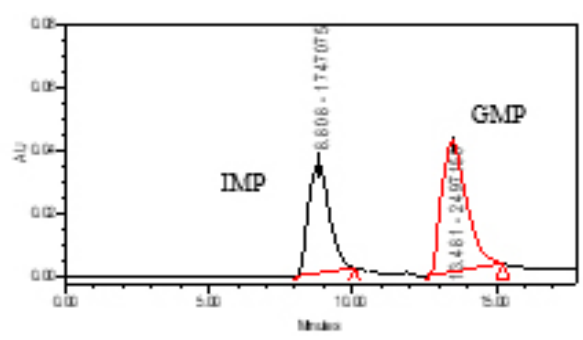

$\mathrm{CH}_{3} \mathrm{COONH}_{4}$

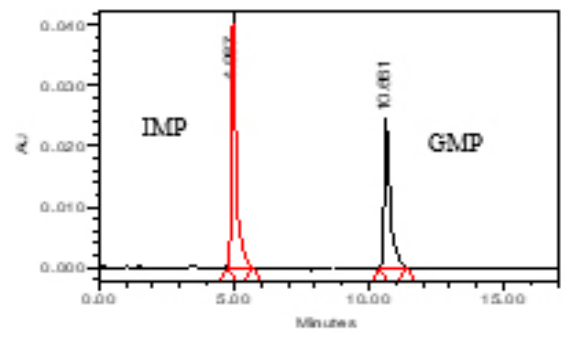

$\mathrm{KH}_{2} \mathrm{PO}_{4}, \mathrm{C}_{7} \mathrm{H}_{15} \mathrm{SO}_{3} \mathrm{Na}$

Figure 1. Chromatograms of IMP and GMP in terms of mobile phase composition

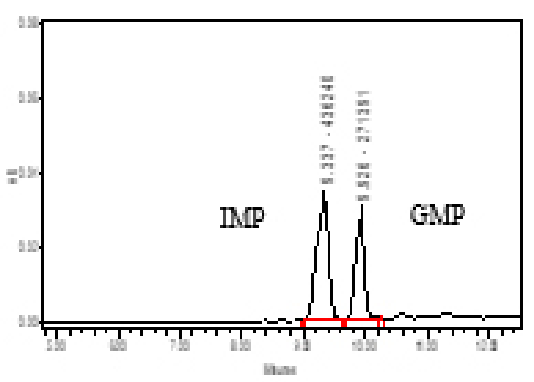

$\mathrm{KH}_{2} \mathrm{PO}_{4} 5 \mathrm{mM}$

$\mathrm{C}_{7} \mathrm{H}_{15} \mathrm{SO}_{3} \mathrm{Na} 2.5 \mathrm{mM}$

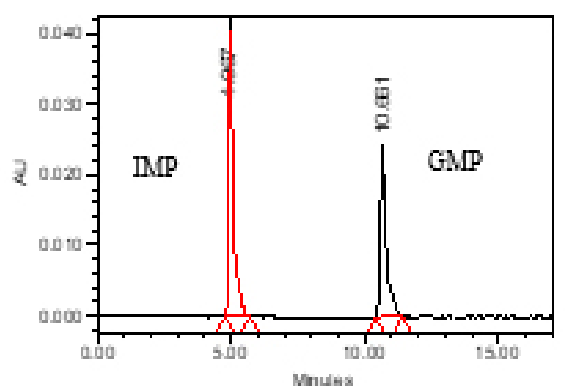

$\mathrm{KH}_{2} \mathrm{PO}_{4} 10 \mathrm{mM}$

$\mathrm{C}_{7} \mathrm{H}_{15} \mathrm{SO}_{3} \mathrm{Na} 5 \mathrm{mM}$

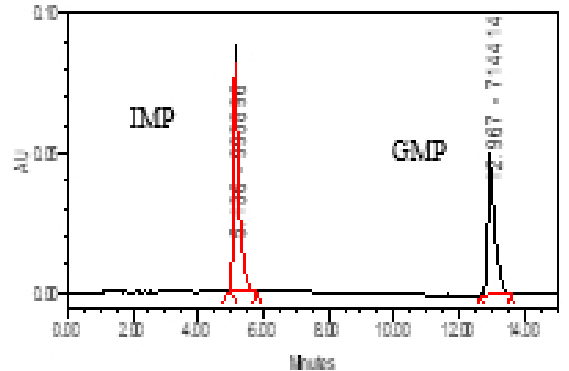

$\mathrm{KH}_{2} \mathrm{PO}_{4} 50 \mathrm{mM}$

$\mathrm{C}_{7} \mathrm{H}_{15} \mathrm{SO}_{3} \mathrm{Na} 25 \mathrm{mM}$

Figure 2. Chromatograms of IMP and GMP in terms of buffer concentration

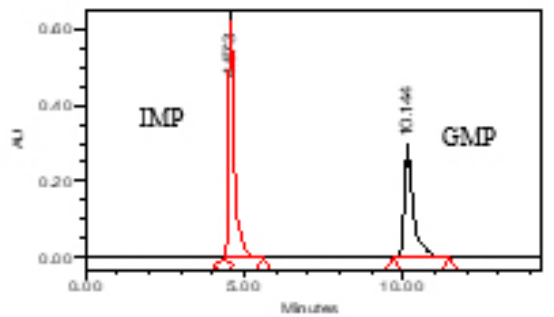

$\mathrm{KH}_{2} \mathrm{PO}_{4}, \mathrm{C}_{7} \mathrm{H}_{15} \mathrm{SO}_{3} \mathrm{Na} \mathrm{pH} 5$

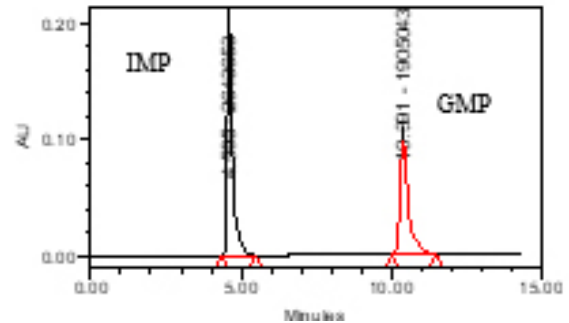

$\mathrm{KH}_{2} \mathrm{PO}_{4}, \mathrm{C}_{7} \mathrm{H}_{15} \mathrm{SO}_{3} \mathrm{Na} \mathrm{pH} 4$

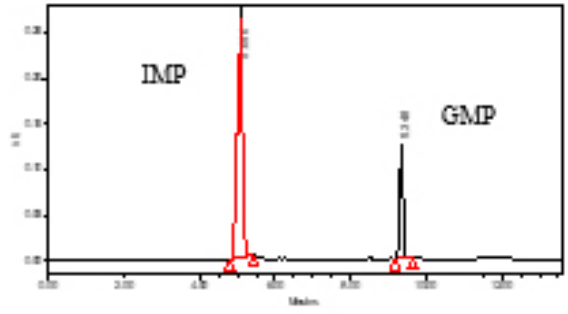

$\mathrm{KH}_{2} \mathrm{PO}_{4}, \mathrm{C}_{7} \mathrm{H}_{15} \mathrm{SO}_{3} \mathrm{Na} \mathrm{pH} 3$

Figure 3. Chromatograms of IMP and GMP in terms of $\mathrm{pH}$

In a summary, HPLC conditons for analyzing IMP and GMP:

- C18 Column $(250 \mathrm{~mm} \times 4.6 \mathrm{~mm} \times 5 \mu \mathrm{m})$

- Mobile phase: $10 \mathrm{mM}$ Potassium dihydrogen phosphate, $5 \mathrm{mM}$ sodium heptanesulfonate, $\mathrm{pH} 3$

- Flow rate: $0.8 \mathrm{~mL} / \mathrm{min}$ 
HPLC conditions were applied to measure the recovery of IMP and GMP in spiked samples when investigating procedure of sample preparation.

\subsection{Sample preparation}

Petroleum ether, hexane, and diethyl ether were examined to remove fat in sausage samples having high fat content. Accurately weighted sausage samples were shaken with $20 \mathrm{~mL}$ organic solvents. After removing fat, samples were extracted with water and analyzed in HPLC to compare extraction performance. The results were shown in Figure 4.

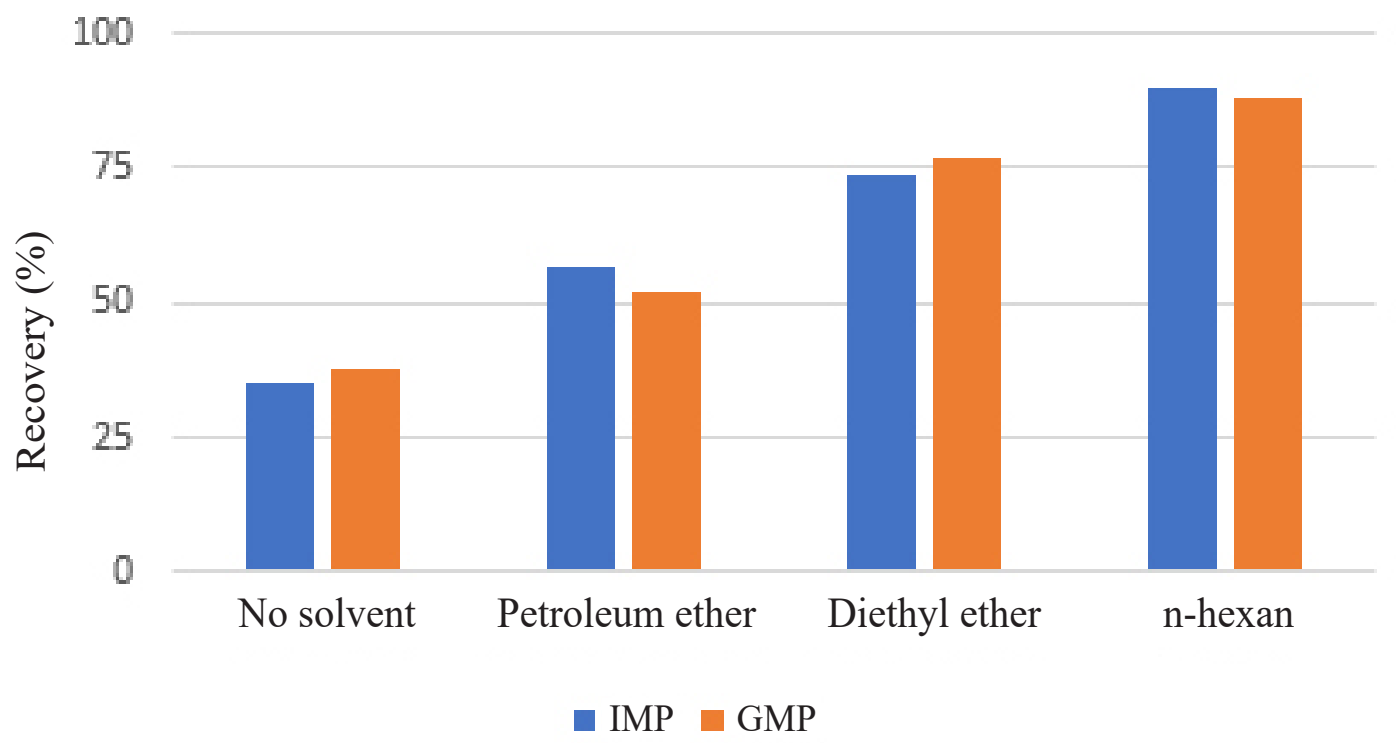

Figure 4. Fat-removing solvents on recovery

Hexane was the most effective solvent to remove fatty substances compared to others. Moreover, using an organic solvent to remove fat out of samples could improve performance of extraction, as well as restricting effect of contaminants on column and HPLC system.

After removing fatty substances by hexane, samples: sausage (high fat content) and sauces (no fat content) were extracted two times with water in a period from 30 - 90 minutes. Recovery of IMP and GMP were the lowest in procedure of 30 minutes in two matrixes (Figure 5,6). They were higher in 60 minutes procedure and insignificant different from 90 minutes procedure.

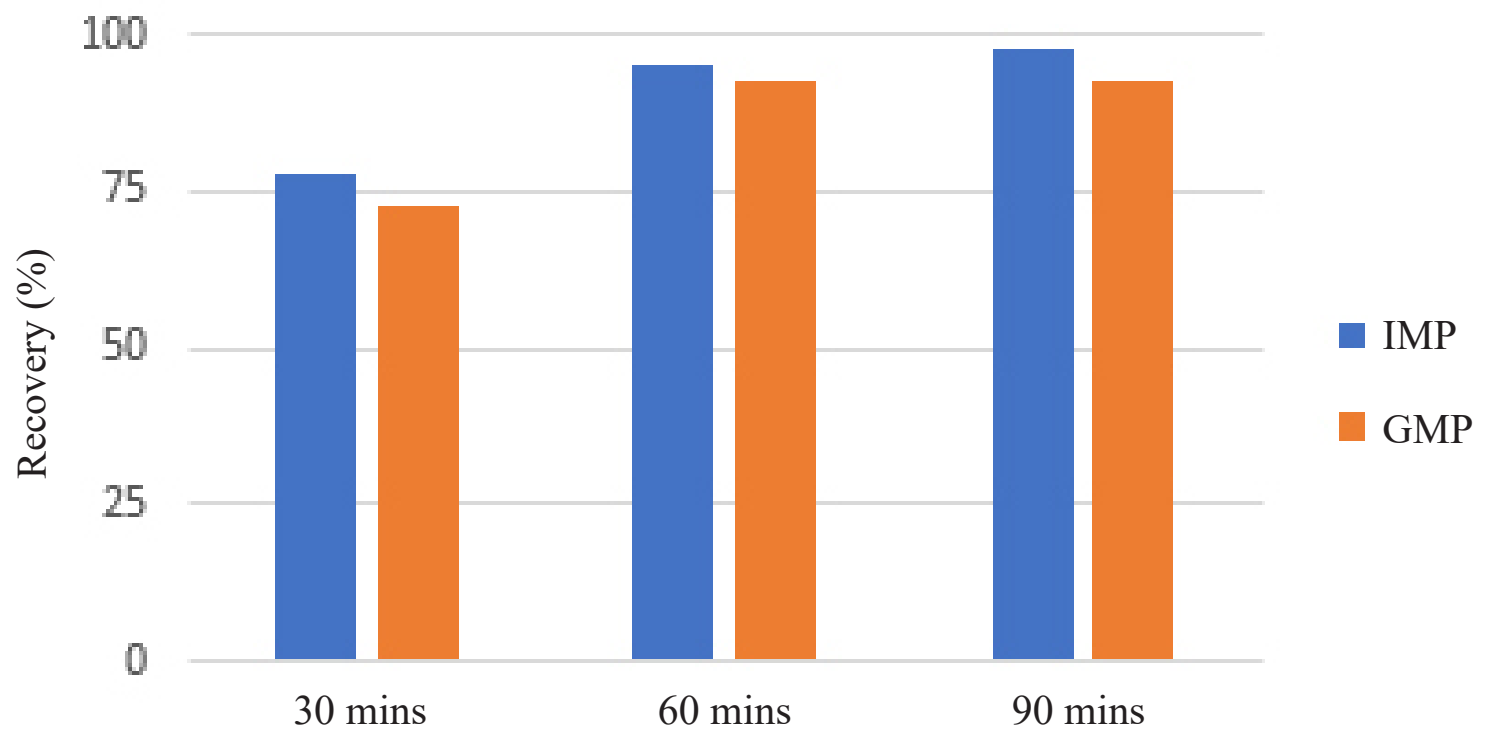

Figure 5. Time of extraction on recovery (fatty matrix) 


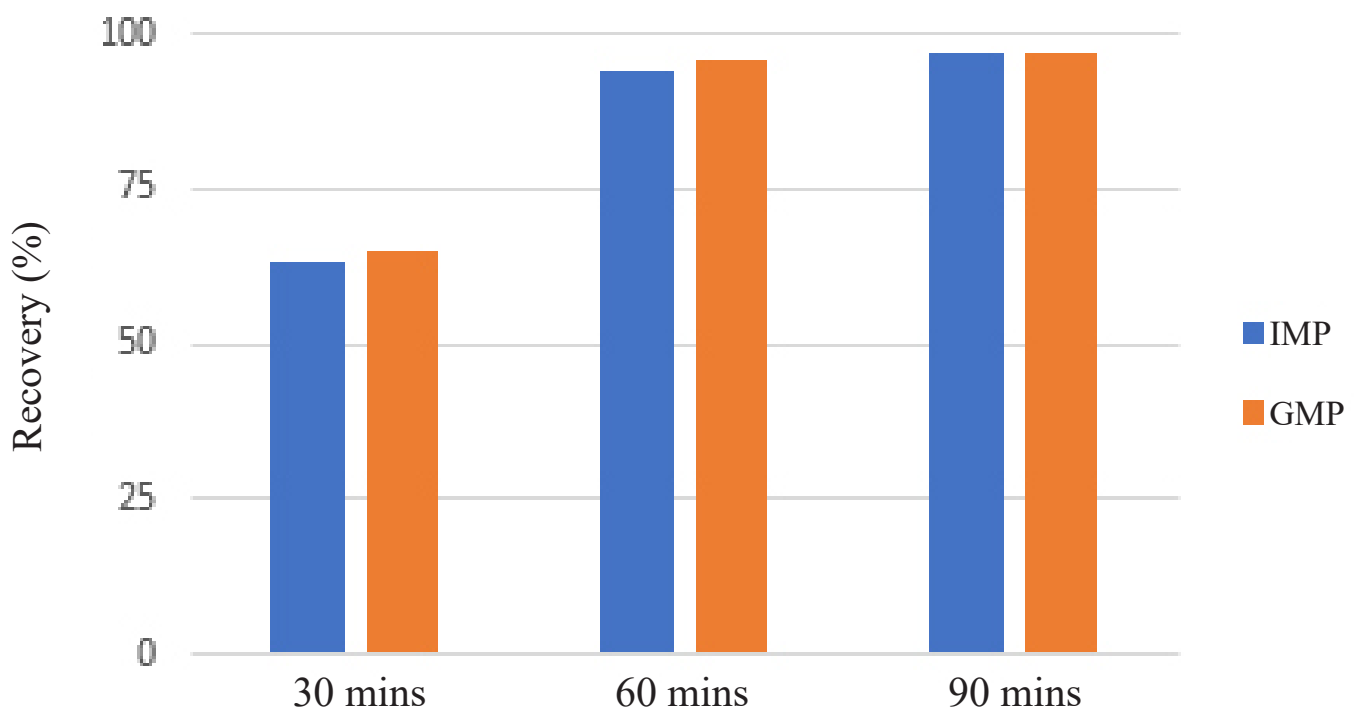

Figure 6. Time of extraction on recovery (non-fatty matrix)

In total the period of 60 minutes, samples were extracted from one to three times. Volume of water for each time of extraction and total of water was equal between procedures. Results showed that there is no difference in recovery of IMP and GMP after two and three times of extractions, while procedure with one time of extraction results in lower recovery rate (Figure 7,8). Accordingly, proce dure with two times of water extractions in total 60 minutes was chosen for analyzing IMP and GMP in this study.

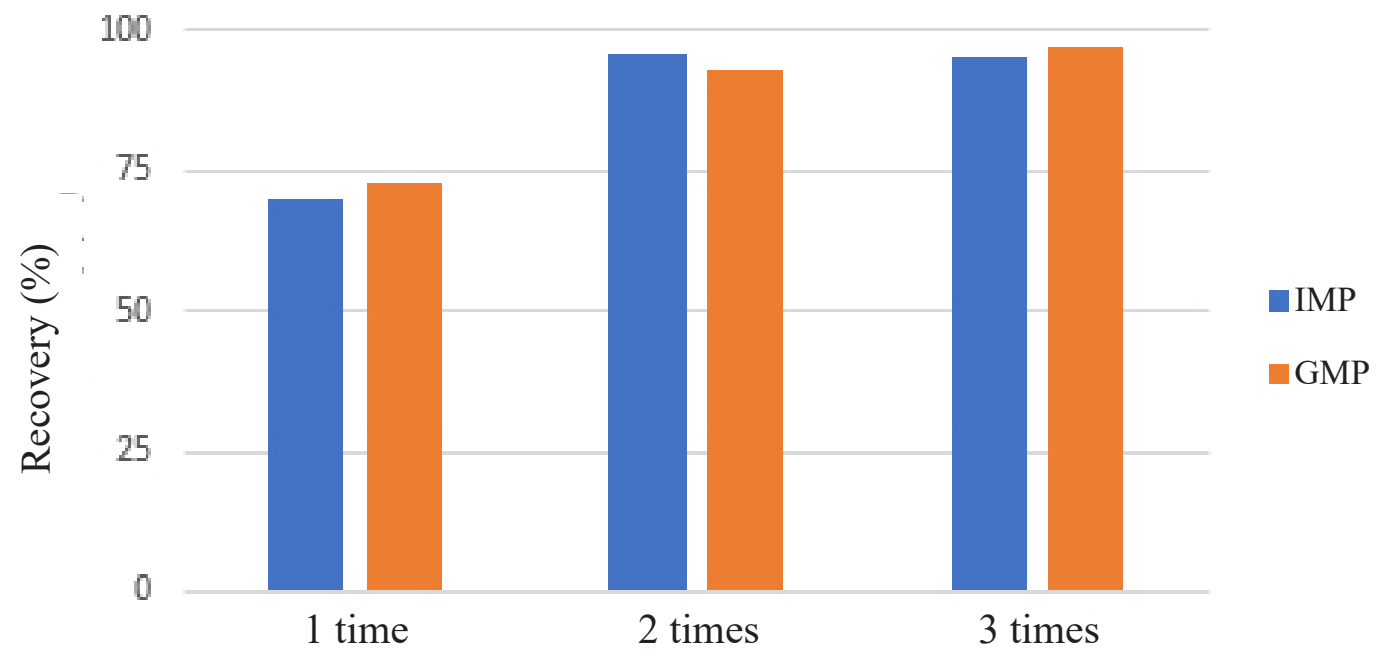

Figure 7. Number of extractions on recovery (fatty matrix)

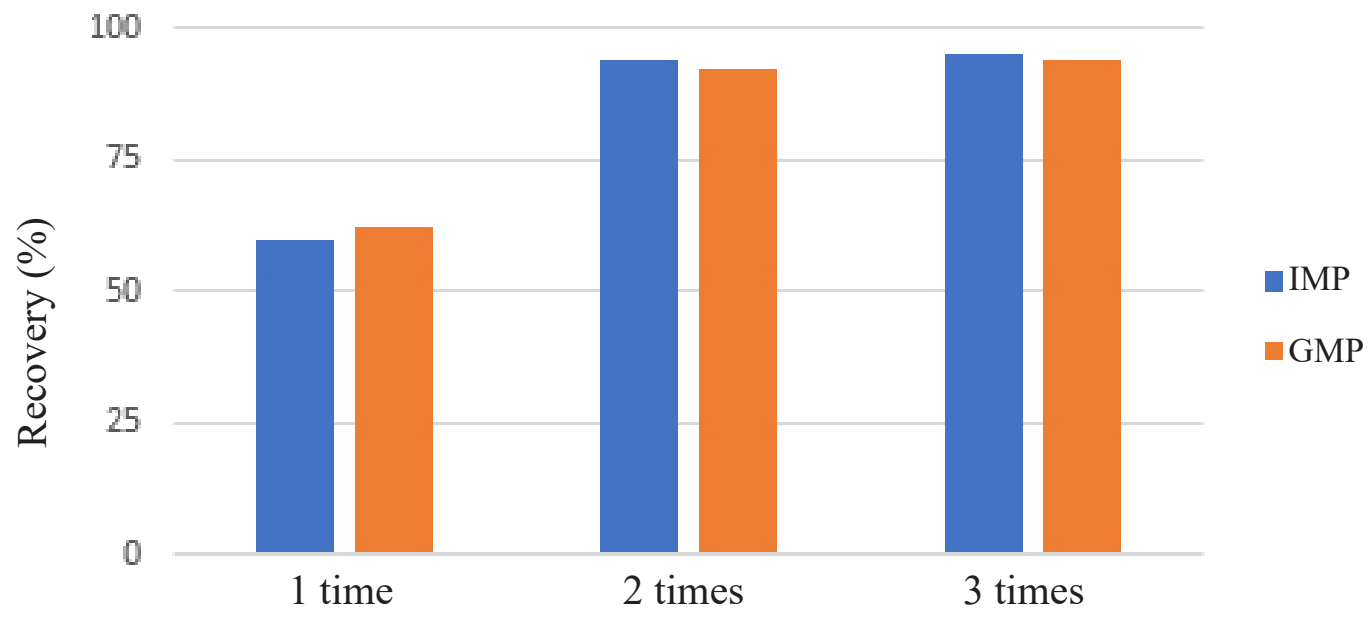

Figure 8. Number of extractions on recovery (non-fatty matrix) 
Summarily, an amount of about $3 \mathrm{~g}$, at nearest $0,1 \mathrm{~g}$, of homogenized samples was weighted to a $50 \mathrm{~mL}$ falcol tube, shaken with $20 \mathrm{~mL}$ hexane. Centrifuging the sample at 6,000 rpm in five minutes. Remove hexane layer by pipetting. Then, samples were extract with $25 \mathrm{~mL}$ water in 30 minutes. Duplicate the extraction with $25 \mathrm{~mL}$ water. Aliquot of the extracts, after centrifuged 6,000 rpm in five mins, were transferred into $50 \mathrm{~mL}$ volumetric flask, then water was added to the mark. The extract was filtered through $0.45 \mu \mathrm{m}$ filters before being injected into HPLC. Chromatographies of analyzing IMP and GMP in food matrices with the extraction procedure were shown in Figure 9.

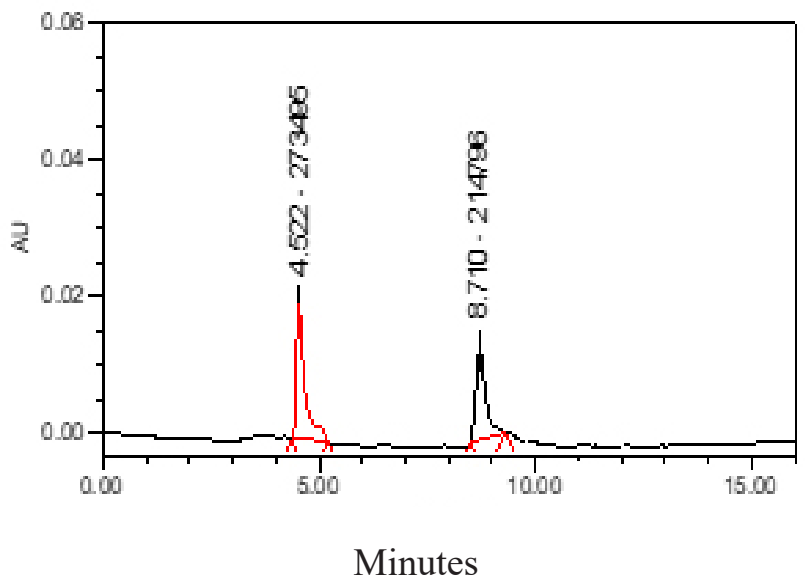

a. Instant noodle sample

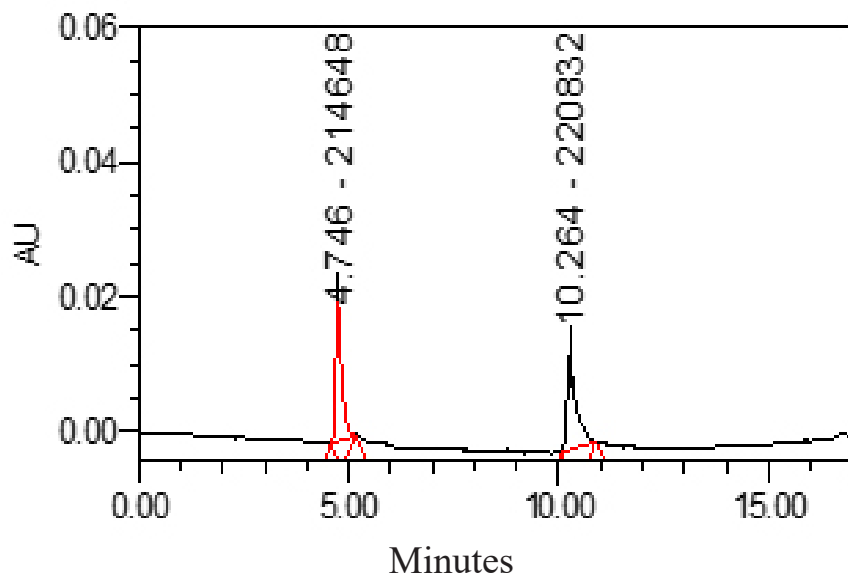

b. Sausage sample

Figure 9. Chromatography of IMP - GMP in food matrices

\subsection{Method validation}

Selectivity: Blank sample, working standards and spiked samples was injected to HPLC. There was no peak appearing in the retention time of IMP and GMP in blank chromatography. The spiked sample had signals at retention times close to that of the standard (difference $<2.5 \%$ ) [8].

Linearity: Calibration curve was performed from five working standards at concentration from $0.5-100 \mathrm{ppm}$. Linear equation of IMP and GMP were $\mathrm{y}=52.825 \mathrm{x}-6144$ and $\mathrm{y}=38.473 \mathrm{x}-10.812$, respectively. Correlation coefficients $\left(\mathrm{R}^{2}\right)$ of two substances were over 0.999 proving high linearity between peak areas and substances' concentration.

Precision was evaluated by spiking IMP and GMP in sausage samples (high content of fat and protein matrix) and instant noodle samples (high content of carbohydrate matrix) at three levels of concentration and calculating the recovery. Recovery of IMP and GMP in instant noodle matrix were from 90.5 to $102.8 \%$ and from 95.5 to $103.9 \%$, respectively. In sausage matrix, recovery of IMP and GMP were from 90.5 to $99.7 \%$ and from 91.5 to $103.5 \%$, respectively (Table 2). The results qualified according AOAC guidelines [9].

Table 2. Recovery of IMP, GMP in food matrices

\begin{tabular}{lcccc}
\hline Matrix & $\begin{array}{c}\text { Spiked IMP } \\
(\mathbf{m g})\end{array}$ & Recovery $(\boldsymbol{R} \%)$ & $\begin{array}{c}\text { Spiked GMP } \\
(\boldsymbol{m g})\end{array}$ & Recovery (R \%) \\
\hline \multirow{3}{*}{ Instant noodle } & 0.25 & $97.7-102.8$ & 0.23 & $95.4-103.9$ \\
& 1.00 & $95.9-97.9$ & 0.46 & $95.6-103.4$ \\
\cline { 2 - 5 } Sausage & 0.125 & $90.7-95.0$ & 0.92 & $95.5-103.6$ \\
& 0.25 & $93.7-99.7$ & 0.14 & $91.5-97.7$ \\
& 0.50 & $95.8-98.1$ & 0.28 & $99.4-103.4$ \\
& & $90.4-90.8$ & 0.56 & $98.0-101.1$ \\
\hline
\end{tabular}


The results of repeatability and reproducibility were shown in Table 3. RSDr and RSDR of IMP and GMP in two matrixes: sausage and instant noodles were acceptable following the guidelines of AOAC at the level of 1,000 ppm [9].

Prepare a spiked sample having IMP and GMP content at $10 \mathrm{mg} / \mathrm{kg}$ (five times of estimated LOD). Analyze the sample ten times to calculate standard deviation and LOD of the method. LOD of the method was $2.32 \mathrm{ppm}$ for IMP $(\mathrm{R}=4,07)$ and $2.77 \mathrm{ppm}$ for GMP $(\mathrm{R}=4,37)$ [8].

Table 3. Repeatability and reproducibility of IMP and GMP in food matrices

\begin{tabular}{lcccccc}
\hline Matrix & $\begin{array}{c}\text { IMP } \\
(\mathbf{m g} / \mathbf{k g})\end{array}$ & $\begin{array}{c}\text { IMP } \\
(\mathbf{m g} / \mathbf{k g})\end{array}$ & $\begin{array}{c}\text { IMP } \\
(\mathbf{m g} / \mathbf{k g})\end{array}$ & $\begin{array}{c}\text { IMP } \\
(\mathbf{m g} / \mathbf{k g})\end{array}$ & $\begin{array}{c}\text { IMP } \\
(\mathbf{m g} / \mathbf{k g})\end{array}$ & $\begin{array}{c}\text { IMP } \\
(\mathbf{m g} / \mathbf{k g})\end{array}$ \\
\hline $\begin{array}{l}\text { Instant } \\
\text { noodle }\end{array}$ & $296-319$ & $\mathbf{1 . 0 9}$ & $\mathbf{2 . 3 2}$ & $377-420$ & $\mathbf{1 . 6 8}$ & 3.07 \\
\cline { 2 - 7 } Sausages & $111-121$ & $\mathbf{1 . 3 7}$ & $\mathbf{2 . 6 7}$ & $176-195$ & $\mathbf{1 . 2 5}$ & 2.83 \\
\hline
\end{tabular}

The method was proved it suitable to analyze IMP and GMP in food matrices with both high concentration of carbohydrate, protein, and fat. Developed method was used to analyze IMP and GMP content in 30 food products collected in Hanoi markets. The food products included ten samples of instant noodle, ten samples of sausage, ten samples of sauces and spices. The results were summarized in Table 4. The highest contents of IMP and GMP were detected in spices and sauces products. Concentration of IMP and GMP in sausages and noodles was far lower than spices products, averagely at $250 \mathrm{ppm}$ for each substance.

Table 4. IMP and GMP content in food products

\begin{tabular}{lcc}
\hline \multicolumn{1}{c}{ Matrix } & IMP $(\mathbf{m g} / \mathbf{k g})$ & $\boldsymbol{G M P}(\mathbf{m g} / \mathbf{k g})$ \\
\hline Instant noodle & $115-509$ & $154-589$ \\
\cline { 2 - 3 } Sausage & $112-151$ & $150-207$ \\
\cline { 2 - 3 } Sauces and spices & $1.129-6.158$ & $1.464-7.147$ \\
\hline
\end{tabular}

Although there is no regulation on IMP and GMP content in food, because of their general safety, IMP and GMP were proved that they related to nucleotid-metabolic distortion such as gout, purin metabolic distortion in children, etc. Therefore, WHO and ministry of health regulated that IMP and GMP were banned in products for children under one year. Authorities also recommended those who are nucleotid-metabolic distortion patients avoid using products containing IMP and GMP. Because IMP and GMP merely increase the taste without nutritious value, consumers should not abuse them in daily diet.

\section{CONCLUSION}

A method to determinate IMP and GMP simultaneously was developed and validated following AOAC criteria: specification, linearity, precision, accuracy, LOD and LOQ. Samples preparation procedure was fast and simple, that comprises shaking with $20 \mathrm{~mL}$ hexane to remove fat, then extracting with water two times in total 60 minutes. The method was applied to analyze three groups of matrices with 30 food products and can be used as a routine method for analyzing IMP and GMP in food. 


\title{
REFERENCES
}

[1]. Qiu W, Chen S, Xie J, Qu Y, and Song X, "Analysis of 10 nucleotides and related compounds in Litopenaeus vannamei during chilled storage by HPLC-DAD," LWT Food Science and Technology, vol. 67, pp.187193, 2016.

[2]. Ministry of Healh, “QCVN 4:1-23:2010/BYT”, 2010.

[3]. V. P. H. Dyta, "Analysis of disodium 5'-guanylate and disodium 5'-inosinate as flavor enhancer in food spices by thin-layer chromatography-densitometry," International Journal of Applied Pharmaceutics, vol. 10, no. 1, pp.51, 2018.

[4]. R. A. F. Pereira, C. Ugucione, and E. R. Pereira-Filho, "Determination of inosine 5'-monophosphate monophosphate (IMP) and guanosine 5'-monophosphate (GMP) in yeast extracts using UV spectroscopy and chemometrics," Brazilian Journal of Food Technology, vol. 21, 2018.

[5]. D. K. Natalia and T. I. Rukmana, "Development of a high-performance liquid chromatography method for analyzing disodium 5'-guanylate and disodium 5'-inosinate levels in flavor enhancers," International Journal of Applied Pharmaceutics, vol. 10, no. 1, pp. 133, 2018.

[6]. L. Coulier, R. Bas, M. Hekman, V. D. Werff, M. Burgering, and U. Thissen, "Comprehensive Analysis of Umami Compounds by Ion-Pair Liquid Chromatography Coupled to Mass Spectrometry," Journal of Food Science, vol. 76, no. 7, pp. 1081-1087, 2011.

[7]. G. Xiao, H. Xiao, Y. Zhu, and Y. You, "Determination of nucleotides in Chinese human milk by high-performance liquid chromatography-tandem mass spectrometry," Dairy Science \& Technology, vol. 94, no. 6, pp. 591-602, 2014.

[8]. T. C. Son, "Method validation in chemical and microbiological analysis,". Ha Noi: Science and Technics Publishing House, 2016.

[9]. AOAC Official Methods of Analysis, Guidelines for Standard Method Performance Requirements, Appendix F, 2016.

\section{Xây dựng phương pháp HPLC phân tích đổng thời Guanosine 5'-monophosphat (GMP) và Inosine 5'-monophosphat (IMP) trong thực phẩm}

\author{
Lê Đình Hải ${ }^{1}$, Nguyễn Thị Thưr ${ }^{2}$, Vũ Thị Trang ${ }^{1}$, Lê Thị Thúy ${ }^{1}$ \\ ${ }^{1}$ Viện Kiểm nghiệm an toàn vệ sinh thực phẩm Quốc gia, Hà Nội, Việt Nam \\ ${ }^{2}$ Truoòng Đại học Bách khoa Hà Nội, Hà Nọi, Việt Nam
}

\section{Tóm tắt}

Nghiên cứu được thực hiện với mục tiêu phát triển phương pháp HPLC để phân tích đồng thời guanosine $5^{\prime}$-monophosphat (GMP) và inosine $5^{\prime}$-monophosphat (IMP) trong một số nền mẫu thực phẩm. Quy trình xử lý mẫu nhanh, đơn giản. Các điều kiện HPLC bao gồm: cột C18 (250 mm × 4,6 mm, $5 \mu \mathrm{m})$ và pha động là hỗn hợp kali dihydrophosphat $10 \mathrm{mM}$ and natri heptansulfonate $5 \mathrm{mM}$, bước sóng phát hiện $250 \mathrm{~nm}$. Phương pháp đã được thẩm định theo các tiêu chí của AOAC. Các tiêu chí độ chọn lọc, tuyến tính $\left(\mathrm{R}^{2}>\right.$ 0,999), độ đúng (với độ thu hồi của IMP: 90,5 - 102,8 \% và GMP: 91,5 - 103,9 \%), độ tái lặp (RSDR của IMP và GMP lần lượt là 3,07 và $2,83 \%$ ) đều đạt yêu cầu của $A O A C$. Giới hạn phát hiện của phương pháp đối với IMP và GMP là 2,32 và $2,77 \mathrm{mg} / \mathrm{kg}$. Phương pháp đã được áp dụng để xác định hàm lượng của IMP và GMP một số sản phẩm thực phẩm trên thị trường Hà Nội.

Tù̀ khóa: GMP, IMP, HPLC, thực phẩm. 